\title{
Executive Overconfidence and Green Innovation
}

\author{
Dandan Wang ${ }^{*}$ \\ ${ }^{1}$ Henan University, Business School, China
}

\begin{abstract}
As one of the important ways to achieve sustainable economic development, enterprise green innovation will also have an important impact on the future development of enterprises. Through the analysis, it is found that green innovation can realize the sustainable development of enterprises. However, green innovation has the characteristics of high risk and double externality, so the enthusiasm of enterprise green innovation is relatively low. As the decision maker of enterprises, the characteristics of management will have an important impact on green innovation. This paper studies the influence of Managerial Overconfidence on green innovation. This paper first studies the impact of management overconfidence on enterprise risk-taking ability, and finds that management overconfidence can improve enterprise risk-taking ability. Then it studies the impact of enterprise risk-taking ability on green innovation. The higher the enterprise risk-taking ability is, the more conducive to the implementation of green innovation activities. Through theoretical analysis, this paper concludes that management overconfidence can further promote the green innovation of enterprises by improving the risk-taking ability of enterprises.
\end{abstract}

\section{Introduction}

Faced with various challenges at home and abroad, China's economy still maintains rapid growth. China's GDP will exceed one hundred billion yuan in 2020, reaching 101.6 trillion yuan. The rapid economic growth is inseparable from the development of industrialization, but the blind pursuit of industrial economic growth has neglected to protect the environment, and serious environmental pollution problems follow. Environmental pollution not only harms people's quality of life, but also harms the economic interests of enterprises and society. In this context, green development has become the common aspiration of the entire society. "Green innovation" is becoming one of the important ways to promote the sustainable development of the economy and the sustainable development of enterprises. However, the current corporate green innovation is still seriously inadequate. As corporate executives are the decision makers of corporate business activities, the characteristics of corporate executives will have an important impact on green innovation. Because green innovation projects face great investment risks, and corporate executives pursue short-term economic benefits of the company based on their own interests, executives generally abandon corporate green innovation activities, but overconfident executives have a strong risk-taking ability and are The forecast of innovation projects is relatively optimistic, so it is inferred that the overconfidence of corporate executives will have a positive impact on corporate green innovation, which has positive significance for stimulating the enthusiasm of corporate green innovation and the construction of China's ecological civilization.

\section{Literature review}

\subsection{Research on Green Innovation}

\subsubsection{Influencing factors of green innovation}

Green innovation is also called environmental innovation, ecological innovation, etc. Green innovation refers to hardware or software innovation related to green products or green processes, including those involving energy conservation, pollution prevention, waste recycling, green product design, and corporate environmental management technologies [1]. At present, domestic and foreign scholars mainly study the influencing factors of green innovation from the inside and outside of enterprises. The external factors affecting green innovation mainly include environmental policies, government subsidies, consumers and suppliers. Previous studies have found that environmental regulations [2] [3], customers and suppliers [4], government subsidies [5], etc. will promote green innovation of enterprises. However, some scholars have found that political resources have a crowding-out effect on corporate green innovation. For example, Nee (2010) found that political resources have a crowding-out effect on green innovation, and political resources can inhibit corporate green innovation [6]. The internal influencing factors mainly include the characteristics of senior management, business performance, corporate governance, and board governance. Scholars have found that the profitability of the company [2] and corporate

* Corresponding author: 2627643664@qq.com 
governance [7] will also promote the company's green innovation through the analysis of the internal resources of the company and the characteristics of the senior management and other green innovation research.

\subsubsection{Economic consequences of green innovation}

At present, scholars mainly study the economic consequences of green innovation from the perspective of Finance and environment. In the production process, enterprises consider saving resources and improving the efficiency of resource utilization, and consider energy conservation and environmental protection in product design, so as to produce differentiated products and improve the competitive advantage of enterprises. Chen (2006) found that green product innovation and green process innovation can improve the competitive advantage of enterprises [1]. Zhang (2019) found that the green innovation of state-owned enterprises can improve the financial performance of enterprises through the study of Chinese listed companies [8]. Through questionnaire survey, Chiou (2011) found that green innovation can improve environmental performance and enhance the global competitive advantage of enterprises [9].

\subsection{Research on Executive Overconfidence}

At present, there are many researches on the impact of Managerial Overconfidence on enterprise investment, financing and innovation at home and abroad, while few scholars pay attention to the impact of Managerial Overconfidence on green innovation. Scholars mostly consider the psychological disadvantage of overconfidence of executives, and think that overconfidence of executives will lead to over investment [10], thus affecting the investment efficiency of enterprises [11], which is not conducive to the future development of enterprises. But in recent years, scholars have found that executive overconfidence has advantages in investment decision-making. Li (2010) found that managerial overconfidence is positively correlated with the level of risk-taking [12]. Galasso (2011) found that managerial overconfidence can improve the innovation performance of enterprises, and this incentive effect is greater in the competitive industry [13].

The current research on the impact of green innovation mainly studies the influencing factors of green innovation from the internal and external levels of the enterprise. The external factors mainly include environmental policies, government subsidies, consumers and suppliers. Internal factors mainly include corporate performance, corporate governance, and management characteristics. Regarding the impact of management characteristics on green innovation, most literature studies the impact of management's gender, management education, and management compensation on green innovation, but few scholars pay attention to the impact of management's overconfidence on green innovation. Therefore, this article studies the impact of management overconfidence on green innovation from the perspective of corporate risk-bearing capacity.

\section{Green innovation and sustainable development of enterprises}

Chen (2006) divided green innovation into green product innovation and green process innovation. Green process innovation includes clean production technology innovation and end treatment technology innovation, which aims to reduce harmful substances, reduce pollutant emissions and improve energy efficiency by improving existing production processes or developing new processes. Green process innovation can effectively improve the resource utilization rate and reduce the generation of waste by using new energy, recycling resources and improving the existing production process, so as to ensure that the production and manufacturing processes of enterprises meet the requirements of environmental regulations, achieve the purpose of saving resources and reducing pollution, and avoid being punished for environmental pollution. Through the innovation of the original production process, we can reduce the waste of resources, improve the efficiency of production, and improve the efficiency of enterprises. In addition, as a cutting-edge technology innovation, green process innovation can bring technology leading edge and improve the ability of environmental governance for enterprises.

Green product innovation mainly emphasizes the integration of environmental protection concept into raw material selection, product design, product packaging and other aspects, so as to reduce the negative impact of the whole product life cycle on the external environment. Green product innovation can reduce the energy consumption of products in the use process by using environmental protection materials, and build a more perfect recycling system, so as to reduce the impact of products on the environment in the whole life cycle. The environmental protection characteristics of green products help enterprises build differentiated competitive advantages, establish a good green image in the market, improve the reputation of enterprises, and improve the trust of stakeholders in the environmental performance of enterprises. The advantage of differentiated products brought by green product innovation can help enterprises increase market share and improve financial performance. Therefore, in the process of implementing green innovation, enterprises can not only improve the utilization rate of resources, save resources and reduce production costs through green process innovation, but also improve their reputation, increase their market share and enhance their competitive advantages through green product innovation, so as to realize their sustainable development. 


\section{Executive Overconfidence and Corporate Risk-taking}

Overconfidence of executives can increase a company's risk-bearing capacity. Mainly manifested in the following three aspects:

First, overconfident management is more optimistic about investment expectations. Overconfident executives believe that the uncertainty of the economic environment has a limited impact on corporate investment, so they believe that the probability of success of the project is relatively high and underestimate the risk of the project. And over-confident executives estimate that the expected return of the investment project will be higher than the actual return of the project, and overestimate the expected return of the investment project. Therefore, the overconfidence of executives will increase the enterprise's risk-bearing capacity for investment projects.

Second, overconfident executives will overestimate their abilities. Overconfident executives believe that they have sufficient knowledge and experience. They believe that they can make more accurate judgments about investment projects and have the ability to deal with unpredictable events. Therefore, in the investment process, overconfident management will prefer high-risk projects.

Finally, the overconfidence of executives can alleviate the principal-agent problem between executives and shareholders. According to the principal-agent theory, shareholders are pursuing long-term sustainable development of the enterprise, while management pursuing short-term economic benefits, so management generally chooses projects with low risk to invest in, and the risk bearing capacity is relatively weak. But at present, most companies do not use the short-term performance of the company alone as the evaluation index for the management. Many companies also include the long-term interests of the company in the evaluation index. Overconfident management believes that they have the ability to create more value for the company and will aim for the company's long-term sustainable development. Therefore, overconfident management will challenge high-risk projects.

\section{Executive Overconfidence and Green Innovation}

Based on the principal-agent theory, the interests of corporate top managers and shareholders are inconsistent. Shareholders pursue the long-term sustainable development of the company, while top managers pursue the short-term economic benefits of the company. Green innovation has significant environmental performance and financial performance, which can realize the sustainable development of enterprises. However, compared with traditional innovation, green innovation has the characteristics of large investment, long investment cycle, and high risk, and green innovation has the "dual externality" of technology and environment. Corporate executives will abandon green innovation in order to avoid risks. Corporate green innovation activities require a certain degree of risk-bearing capacity.

Overconfident management will help promote the company's green innovation activities. First, overconfident management has strong risk-taking ability. Because green innovation activities have high-risk characteristics, under normal circumstances, management will pursue the short-term interests of the enterprise and give up the long-term development of the enterprise in order to realize its own interests. Therefore, management is unwilling to carry out green innovation activities in order to avoid risks. Confident management is more optimistic about investment projects and believes that they have the ability to deal with uncertain events in green innovation, which will enhance the company's risk tolerance. Therefore, the overconfidence of the management will increase the risk tolerance of the company to green innovation, thereby promoting the implementation of green innovation.

Secondly, with the general improvement of residents' green awareness, green innovation has attracted more and more attention from the market. Overconfident executives value their reputation and believe that they are capable of meeting the needs of stakeholders. Because green innovation has environmental externalities, it will be recognized by stakeholders such as the government, investors, suppliers, consumers, etc., and the management will improve their reputation and stimulate the management's enthusiasm for green innovation. Moreover, green innovation has significant financial performance, which can improve the competitive advantage of the enterprise and realize the long-term sustainable development of the enterprise. This will bring a sense of accomplishment to the executives and stimulate the enthusiasm of management for green innovation. Therefore, the overconfidence of corporate executives will promote the company's green innovation.

\section{Conclusion}

Green process innovation can improve the financial performance of enterprises by improving resource utilization and reducing production costs. Green product innovation improves the competitive advantage of enterprises by building differentiated product advantages, so as to improve the market share of enterprises. Therefore, the green innovation of enterprises can realize the sustainable development of enterprises. However, due to the immaturity of green technology, green innovation has double externalities of technology and environment, and the risk of green innovation is difficult to predict. The investment of green innovation projects requires enterprises to bear certain risks. For the pursuit of short-term interests of the management, in order to achieve the short-term interests of enterprises, they will choose to avoid risks and give up the green innovation of enterprises. Based on the analysis of the characteristics of management overconfidence, this paper finds that the overconfident management is optimistic about the enterprise investment project, and thinks that they have 
enough ability to deal with the uncertainty and risk of the project, so the overconfidence of management will improve the enterprise's risk-taking ability. The improvement of enterprise risk-taking ability will promote the green innovation of enterprises. Therefore, it can be concluded that management overconfidence can promote the green innovation of enterprises by improving the risk-taking ability of enterprises.

\section{Suggestion}

Enterprises should take the initiative to pay attention to the demands of stakeholders. With the general improvement of residents' awareness of environmental protection, enterprises should realize the importance of green innovation to the sustainable development of enterprises, actively implement green innovation, and improve the competitive advantage of enterprises. Enterprises should pay attention to the influence of executives' psychological characteristics. Enterprises should bring managers' overconfidence and other psychological characteristics into the process of executive appointment and management, optimize the decision-making mechanism, standardize the decisionmaking process, and give full play to managers' psychological characteristics, such as managers' overconfidence, to promote the green innovation management and performance improvement of enterprises. Enterprise green innovation has the characteristics of high risk, but it can improve the financial performance and environmental performance of the enterprise. The enterprise management should establish a correct investment view, and should not give up the projects that are conducive to the long-term sustainable development of the enterprise in order to avoid the risk. When selecting talents, enterprises should pay attention to the psychological characteristics of overconfidence of enterprise management, conduct comprehensive evaluation on the psychological quality of management, so as to select more high-quality talents for enterprises and do a good job in risk control of enterprise human resources.

This paper makes an in-depth theoretical analysis of the importance of green innovation and the impact mechanism of executive overconfidence on green innovation. However, there are some limitations in this paper: This paper is only a theoretical analysis of the impact of green innovation and executive overconfidence on green Innovation, lack of empirical evidence, how to better test the relationship between executive overconfidence and green innovation needs further research.

\section{References}

1. Y.S. Chen, S.B. Lai, C.T. Wen, J. Bus. Ethics 67, 4 (2006)

2. D. Li, M. Zheng, C. Cao, X. Chen, S. Ren, M. Huang, J. Clean. Prod 141 (2017)
3. P. Berrone, A. Fosfuri, L. Gelabert, M.L.R. Gomez, Strategic. Manage. J 34, 8 (2013)

4. J.W. Huang, Y.H. Li, J. Bus. Ethics 145, 2 (2017)

5. X. Xie, J. Huo, G. Qi, IEEE. T. Eng. Manage 63, 1 (2016)

6. V. Nee, S. Opper, Soc. Forces 88, 5 (2010)

7. M.D. Amore, M. Bennedsen, J. Environ. Econ. Manage 75 (2016)

8. D. Zhang, Z. Rong, Q. Ji, Resour. Conserv. Recy 144 (2019)

9. T.Y. Chiou, H.K. Chan, F. Lettice, S.H. Chung, Transport. Res. E-Log 47, 6 (2011)

10. A.M. Goel, A.V. Thakor, J. Financ 63, 6 (2008)

11. J.B. Heaton, Financ. Manage 31, 2 (2002)

12. J. Li, Y. Tang, Acad. Manage. J 53, 1 (2010)

13. A. Galasso, T.S. Simcoe, Manage. Sci 57, 8 (2011) 